\title{
PERFORMANCE OF BARI DEVELOPED USG APPLICATOR IN BORO RICE FIELD
}

\author{
M. A. Rahaman ${ }^{1}$, M. M. Rahman ${ }^{2}$, M. M. Uddin ${ }^{3}$, M. Ahmed ${ }^{4}$ and S. Roy ${ }^{5}$ \\ $1 \& 5$ Scientific Officer, ${ }^{2}$ Senior Scientific Officer, ${ }^{3}$ Principal Scientific Officer, OFRD, BARI, Tangail and \\ ${ }^{4}$ Scientific Officer, Vertebrate Pest Division, BARI, Gazipur. \\ Corresponding author: ofrdtangail@gmail.com
}

Key words: USG applicator, boro rice

\begin{abstract}
A trial was conducted at the FSRD site, Elenga and MLT site, Ghatail, Tangail during 2011-12 and 2012-13 to test the performance of the BARI developed USG applicator in boro rice and to find out the economic performance of the USG applicator in the farmers' field. The BARI developed USG applicator was tested against the USG application by hand and the conventional method of granular urea application. The average higher grain yield $\left(7.05 \mathrm{t} \mathrm{ha}^{-1}\right.$ and $\left.7.07 \mathrm{t} \mathrm{ha}^{-1}\right)$ of two years were obtained from the plot of USG application with BARI applicator in the both locations, respectively The highest gross return (120410 Tk. ha-1 \& $20290 \mathrm{Tk}^{-} \mathrm{ha}^{-1}$ ) and gross margin (64346 Tk. ha $^{-1}$ and $62164 \mathrm{Tk} \mathrm{ha}^{-1}$ ) during 1011-12 and 2012-13 were obtained from the plots treated with USG by BARI applicator at the FSRD site Elenga and MLT site Ghatail, respectively. Field efficiency of BARI USG applicator and hand application was 0.12 hah $^{-1}$ and 0.027 hah $^{-1}$, respectively. BARI USG applicator saved time $77.65 \%$ compared to that of hand application of USG in boro rice field. It also saved labor cost against the USG application by hand and reduces 33\% urea over the granular urea application in conventional method.
\end{abstract}

\section{Introduction}

Urea is the main sources of $\mathrm{N}$ fertilizer. Nitrogen is an important nutrient element for rice production. It is needed in each and every crop in large quantity. Among the fertilizers, the use efficiency of nitrogenous fertilizers is lowest due to its various losses. $\mathrm{N}$ loss processes are ammonia volatilization, denitrification, runoff, seepage, leaching and many other ways. Only 20$25 \%$ of the total applied $\mathrm{N}$ fertilizer can be received by the rice plant (BRRI, 2007). The low level of $\mathrm{N}$ used by rice plant is generally caused its huge losses in the soil/water/plant complex system. The nature and degree of loss depend upon soil and climatic conditions, nitrogenous fertilizer and flood-water management practices. Many efforts have been made to improve fertilizer use efficacy in lowland rice production. Among them application of urea super granule (USG) is strongly considered to be an important alternative that increase the efficiency of N about 20-25\% and also increase the yield by 15-20\% (BRRI, 2008). USG gave 33-48\% higher grain yield than prilled urea and save $83-90 \mathrm{~kg}$ urea ha ${ }^{-1}$ which was $32-34 \%$ lowers than BRRI recommended rate (Haque et al., 2013a). Urea in the form of USG (Urea Super Granule) has been proved to be superior to prilled urea in all aspects. It is applied in the rice field only for one time after 7 to 10 days of plantation of seedlings and it contributes for the whole growing period of rice.

Deep placement of USG in the root zone enhanced the fertilizer use efficiency of rice which offered environmental and economic benefits (IFPRI, 2004). Depending on agro climate and nitrogen use, deep-placed USG can save of urea fertilizer of up to $65 \%$ with an average of $33 \%$ and increase grain yields up to $50 \%$ with an average of $15 \%$ to $20 \%$ over the same amount of 
Rahaman et al.

split-applied nitrogen as prilled urea, especially in the lower range of nitrogen rates (Savant and Stangel, 1990). Hand placement of urea super granulates of 1-3g size into soil of flood water has resulted in less loss of $\mathrm{N}$, greater $\mathrm{N}$ recovery and higher yield than the conventional $\mathrm{N}$ application method. Unfortunately, farmers have not been able to extract benefit from these findings, primarily, because, they have no suitable fertilizer placement equipment. Deep placement by hand requires more labors and costs. USG application by hand is labor intensive and very slow i.e. 0.07 to $0.12 \mathrm{ha} /$ workday (Savant et al., 1992). To solve the problem in deep placement of urea, FMP Engineering Division of BARI has developed an USG applicator for puddle rice field which is light in weight $(9 \mathrm{~kg})$ and requires only 1 to 1.25 hours for one bihga USG application (Wahab et al., 2010). Farm Machinery and Postharvest Process Engineering (FMPE) Division of BARI also modified the USG applicator for variable row spacing $(17-25 \mathrm{~cm})$ reduced weight from 9 to $6 \mathrm{~kg}$ which field capacity and efficiency were $0.139 \mathrm{ha} \mathrm{h}^{-1}$ and $81 \%$ (Haque et al., 2013b). The applicator needs more tests in farmers' field condition. This trial was undertaken to test the field performance of the USG applicator developed at BARI and to find out the economic performance of the applicator.

\section{Materials and Methods}

The trial was conducted at the FSRD site, Elenga and the MLT site Ghatail, Tangail during 201112 and 2012-13 to test the performance of the BARI developed USG applicator in boro rice in the farmers' field. It was laid out in RCB design with six dispersed replications (farmer). Three treatments were viz. $T_{1}=$ USG application developed by BARI USG applicator, $T_{2}=$ USG application by hand and $\mathrm{T}_{3}=$ Prilled urea application in conventional method. The unit plot size was $20 \mathrm{~m} \times 10 \mathrm{~m}$ and plant spacing was $25 \mathrm{~cm} \times 15 \mathrm{~cm}$. In conventional system, granular urea was applied @ $260 \mathrm{~kg} \mathrm{ha}^{-1}$ in two installments as top dress where two-third at 13 days after transplanting (DAT) and rest one-third at 35 DAT. While, recommended dose of urea for boro rice as USG (175 kg ha-1, 33\% less than the recommended prilled urea) was applied by the applicator once at 8 DAT. Other fertilizers were applied as recommendation in both the two treatments. The rice variety BRRI dhan29 was used as the planting material. The rice seedlings were transplanted during 22-25 January, 2012 and 08-11 February, 2013 at the FSRD site, Elenga and during 26-30 January, 2012 and 02-06 February, 2013 at the MLT site Ghatail, respectively. Intercultural operations such as weeding, gap filling, irrigation, disease and other pest managements were done as and when necessary. The crop was harvested during 11-15 May, 2012 and 02-05 June, 2013 at the FSRD site, Elenga and during13-17 May, 2012 and 22-26 May, 2013 at the MLT site Ghatail. The data on different plant characters and yield component were recorded plot wise and were analyzed statistically using Crop Stat package.

\section{Results and Discussion}

Yield and yield attributes were significantly influenced by the urea application method (Table 1 and 2). The longest plants $(93.57 \mathrm{~cm}$ and $93.76 \mathrm{~cm})$ were observed in the plot of USG application with BARI applicator and the shortest plants $(89.33 \mathrm{~cm}$ and $92.62 \mathrm{~cm})$ were found in granular urea in conventional method at the FSRD site Elenga and MLT site Ghatail, respectively. The maximum filled grains number panicle ${ }^{-1}$ (103.60 and 113.31) were obtained from the plot of USG application with BARI applicator, while the plot with granular urea in conventional method provided minimum number of grains panicle $e^{-1}$ (95.43 and 103.89) at both the locations. Significantly the highest 1000 grain weight $(22.93 \mathrm{~g}$ and $22.68 \mathrm{~g})$ were recorded from the plot of USG application with BARI applicator, while the plot with granular urea in 
Performance of USG Applicator

conventional method provided minimum number of 1000-grains weight $(22.67 \mathrm{~g}$ and $22.12 \mathrm{~g})$ at both the locations, respectively. The highest average grain yield $\left(7.05 \mathrm{tha}^{-1}\right.$ and $\left.7.07 \mathrm{th} \mathrm{a}^{-1}\right)$ were obtained from the plot of USG application with BARI applicator and average lowest yield $\left(6.10 \mathrm{t} \mathrm{ha}^{-1}\right.$ and $\left.6.01 \mathrm{t} \mathrm{ha}^{-1}\right)$ were in the plot of granular urea in conventional method at the FSRD site Elenga and at the MLT site Ghatail, respectively. As the number of filled grains panicle $^{-1}$ and 1000-grains weight were higher in the plot of USG application with BARI applicator, the higher yield obtained in that system is justified. In cost and return analysis (Table 3 and 4), the highest gross return (120410.00 Tk. ha-1 and $120290.00 ~ \mathrm{Tk}^{-1} \mathrm{ha}^{-1}$ ) and gross margin (64346.00 Tk. ha- ${ }^{-1}$ and $62164.00 \mathrm{Tk}$. ha-1) were obtained from the treatment of USG application with BARI applicator at the FSRD site Elenga and at the MLT site Ghatail, respectively. The lowest gross return (104540.00 Tk. ha ${ }^{-1}$ and $103430.00 \mathrm{Tk}^{\mathrm{h}}$ ha $\left.{ }^{-1}\right)$ and gross margin (45573.00 Tk. ha- ${ }^{-1}$ and $43745.00 \mathrm{Tk}^{-} \mathrm{ha}^{-1}$ ) were obtained from the plots where granular urea was applied in conventional method at the both locations.

Table 1. Yield performance of Boro rice (BRRI dhan29) as influenced by BARI USG applicator at the FSRD site, Elenga, Tangail during 2011-12 and 2012-13

\begin{tabular}{|c|c|c|c|c|c|c|c|}
\hline \multirow{2}{*}{$\begin{array}{c}\text { Treatments } \\
\text { (Urea application method) }\end{array}$} & \multirow{2}{*}{$\begin{array}{l}\text { Plant } \\
\text { height } \\
(\mathrm{cm})\end{array}$} & \multirow{2}{*}{$\begin{array}{c}\text { Filled } \\
\text { grains } \\
\text { panicle } \\
\text { (no.) }\end{array}$} & \multirow{2}{*}{$\begin{array}{l}1000- \\
\text { grain } \\
\text { wt. (g) }\end{array}$} & \multicolumn{3}{|c|}{ Grain yield (t ha-1) } & \multirow{2}{*}{$\begin{array}{c}\text { Straw } \\
\text { yield } \\
\left(\mathrm{t} \text { ha }{ }^{-1}\right)\end{array}$} \\
\hline & & & & $\begin{array}{c}2012- \\
13\end{array}$ & $\begin{array}{c}\text { 2011- } \\
12\end{array}$ & Average & \\
\hline $\begin{array}{c}\mathrm{T}_{1}=\text { USG application with } \\
\text { BARI applicator }\end{array}$ & 93.57 & 103.60 & 22.93 & 6.84 & 7.25 & 7.05 & 7.33 \\
\hline $\begin{array}{l}\mathrm{T}_{2}=\text { USG application by } \\
\text { hand }\end{array}$ & 92.77 & 102.63 & 22.83 & 6.68 & 7.15 & 6.92 & 7.26 \\
\hline $\begin{aligned} \mathrm{T}_{3}=\text { Granular urea with } \\
\text { conventional method }\end{aligned}$ & 89.33 & 95.43 & 22.67 & 5.89 & 6.30 & 6.10 & 6.52 \\
\hline $\operatorname{LSD}_{(0.05)}$ & 1.33 & 4.05 & 0.82 & 0.42 & 0.34 & - & 0.40 \\
\hline CV (\%) & 1.10 & 3.10 & 2.80 & 5.10 & 3.80 & - & 4.50 \\
\hline
\end{tabular}

Table 2.Yield performance of Boro rice (BRRI dhan29) as influenced by BARI USG applicator at the MLT site Ghatail, Tangail during 2011-12 and 2012-13

\begin{tabular}{|c|c|c|c|c|c|c|c|}
\hline \multirow{2}{*}{$\begin{array}{l}\text { Treatments } \\
\text { (Urea application method) }\end{array}$} & \multirow{2}{*}{$\begin{array}{l}\text { Plant } \\
\text { height } \\
(\mathrm{cm})\end{array}$} & \multirow{2}{*}{$\begin{array}{l}\text { Filled } \\
\text { grains } \\
\text { panicle } \\
\text { (no.) }\end{array}$} & \multirow{2}{*}{$\begin{array}{c}1000 \\
\text { grain } \\
\text { wt. } \\
\text { (g) }\end{array}$} & \multicolumn{3}{|c|}{ Grain yield $\left(\mathrm{t} \mathrm{ha}{ }^{-1}\right)$} & \multirow{2}{*}{$\begin{array}{c}\text { Straw } \\
\text { yield } \\
(\mathrm{t} \text { ha-1) }\end{array}$} \\
\hline & & & & $\begin{array}{l}2012- \\
13\end{array}$ & $\begin{array}{l}2011- \\
12\end{array}$ & Average & \\
\hline $\begin{array}{c}\mathrm{T}_{1}=\text { USG application with } \\
\text { BARI applicator }\end{array}$ & 93.76 & 113.31 & 22.68 & 6.96 & 7.18 & 7.07 & 7.12 \\
\hline $\begin{array}{l}\mathrm{T}_{2}=\text { USG application by } \\
\text { hand }\end{array}$ & 93.49 & 112.03 & 22.41 & 6.80 & 7.05 & 6.93 & 7.07 \\
\hline $\begin{aligned} \mathrm{T}_{3}=\text { Granular urea with } \\
\text { conventional method }\end{aligned}$ & 92.62 & 103.89 & 22.12 & 6.08 & 5.93 & 6.01 & 6.64 \\
\hline $\mathrm{LSD}_{(0.05)}$ & 1.51 & 5.38 & 1.02 & 0.48 & 0.28 & - & 0.63 \\
\hline CV (\%) & 1.30 & 3.80 & 3.50 & 5.70 & 3.20 & - & 7.00 \\
\hline
\end{tabular}


Rahaman et al.

Table 3. Cost and return analysis of Boro rice (BRRI dhan29) production as influenced by BARI USG applicator at the FSRD site Elenga, Tangail during 2012-13

\begin{tabular}{|c|c|c|c|}
\hline $\begin{array}{c}\text { Treatments } \\
\text { (Urea application method) }\end{array}$ & $\begin{array}{l}\text { Gross return } \\
(\text { Tk. ha-1) }\end{array}$ & $\begin{array}{l}\text { Total variable cost } \\
(\text { Tk. ha-1) }\end{array}$ & $\begin{array}{l}\text { Gross margin } \\
\left(\mathrm{Tk} . \mathrm{ha}^{-1}\right)\end{array}$ \\
\hline $\begin{array}{l}\mathrm{T}_{1}=\text { USG application with BARI } \\
\text { Applicator }\end{array}$ & 120410 & 56064 & 64346 \\
\hline $\mathrm{T}_{2}=$ USG application by hand & 118320 & 59584 & 58736 \\
\hline $\begin{array}{l}\mathrm{T}_{3}=\text { Granular urea in conventional } \\
\text { Method }\end{array}$ & 104540 & 58967 & 45573 \\
\hline
\end{tabular}

Table 4. Cost and return analysis of Boro rice (BRRI dhan29) production as influenced by BARI USG applicator at the MLT site Ghatail, Tangail during 2012-13

\begin{tabular}{|c|c|c|c|}
\hline $\begin{array}{c}\text { Treatments } \\
\text { (Urea application method) }\end{array}$ & $\begin{array}{l}\text { Gross return } \\
\left(\text { Tk. ha }{ }^{-1}\right)\end{array}$ & $\begin{array}{c}\text { Total variable cost } \\
\left(\mathrm{Tk}^{\mathrm{h}} \mathrm{ha}^{-1}\right)\end{array}$ & $\begin{array}{l}\text { Gross margin } \\
\left(\mathrm{Tk} . \mathrm{ha}^{-1}\right)\end{array}$ \\
\hline $\begin{array}{l}\mathrm{T}_{1}=\text { USG application with BARI } \\
\text { applicator }\end{array}$ & 120290 & 58126 & 62164 \\
\hline $\begin{array}{l}\mathrm{T}_{2}=\text { USG application by hand } \\
\mathrm{T}_{3}=\text { Granular urea in conventional } \\
\text { method }\end{array}$ & 118090 & 61125 & 56965 \\
\hline
\end{tabular}

Unit price $\left(\mathrm{Tk} . \mathrm{kg}^{-1}\right)$ : Rice $=15.00$, Rice straw $=2$, Urea $=20.00, \mathrm{TSP}=22.00, \mathrm{MoP}=15.00$, Gypsum $=10.00$, Zinc sulphate $=100.00$ and Boric acid $=150.00$

Performance of USG applicator is shown in Table 5. Average operating time and field capacity of USG applicator were $8.25 \mathrm{~h} \mathrm{ha}^{-1}$ and $0.12 \mathrm{ha} \mathrm{h}^{-1}$.

Table 5. Performance of USG applicator at OFRD, BARI, Tangail during 2011-12 and 2012-13

\begin{tabular}{|c|c|c|c|}
\hline \multirow[t]{2}{*}{ Parameters } & \multicolumn{3}{|c|}{ Locations } \\
\hline & FSRD site Elenga & MLT site Ghatail & Mean \\
\hline \multicolumn{4}{|c|}{ USG applicator: } \\
\hline Operating time $/ \mathrm{h} \mathrm{ha}^{-1}$ & 8.05 & 8.45 & 8.25 \\
\hline Field capacity / ha $\mathrm{h}^{-1}$ & 0.124 & 0.118 & 0.12 \\
\hline \multicolumn{4}{|c|}{ Hand Application: } \\
\hline Operating time $/ \mathrm{h} \mathrm{ha}^{-1}$ & 36.46 & 37.38 & 36.92 \\
\hline Field capacity / ha $\mathrm{h}^{-1}$ & 0.0274 & 0.0267 & 0.027 \\
\hline \multicolumn{4}{|c|}{ Comparison: } \\
\hline Time saved over hand a & $=77.65$ & & \\
\hline
\end{tabular}

\section{Conclusion}

From two years study (2011-12 and 2012-13) it may be concluded that crops with USG applied with BARI USG applicator had about 16\% higher yield than that with granular urea application . BARI developed USG applicator can save time (77.65\%) and labor cost against the USG application by hand. It also reduced 33\% urea over the granular urea application in conventional method. This applicator use is very simple and easy and thus the applicator will be popular among the farmers day by day. Therefore, the technology may be recommended as extension message for using the applicator in large scale. 
Performance of USG Applicator

\section{References}

BRRI (Bangladesh Rice Research Institute). 2007. Impact of LCC and USG on rice production in some selected areas. Annual Research Review report, Agricultural Economics Division, Bangladesh Rice Research Institute, Gazipur. pp.14-17.

BRRI (Bangladesh Rice Research Institute). 2008. "Adhunik Dhaner Chash", Bengali Version, Bangladesh Rice Research Institute, Gazipur-1701. pp.26-64.

Haque, M. A., M. S. Hossain, M. M. Ali and M. A. Rahman. 2013a. Evaluation of different methods of urea applicator and weed control measures for maximizing Boro rice productivity. Bangladesh Agron. J. 16(2): 1-8.

Haque, M., M. A. Wohab, M. A. Hossain, K. K. Saha and M. S. Hassan. 2013b. Improvement and Evaluation of BARI USG Applicator. Agric. Eng. Intl: CIGR J. 15(2):87-94.

IFPRI. 2004. Annual Report, 2003-2004. International Food Policy Research Institute (IFPRI): Wasington, DC, USA. p.74.

Savant, N. K., and P. J. Stangel. 1990. Deep placement of urea super granules in transplanted rice: Principles and practices. Nutrient Cycling in Agroecosys., 25(1): 1-83.

Savant, N. K., P. S. Ongkingco, F.D. Garcia, S. S. Dhane, R. R. Khadse, S. A. Chavan, and K. S. Rao. 1992. Agronomic performance of urea briquette applicator in transplanted rice. Nutrient Cycling in Agroecosys., 32(2): 139-142.

Wahab, A. M., M. E. Haque, M. I. Hossain and M. S. Hossain. 2010. "BARI Guti Urea proyog jontrer karjopronali o babohar", Bengali Version, Farm Machinery and Postharvest Process engineering Department, Bangladesh Agricultural Research Institute, Gazipur1701. 